\title{
Yield and pomological characteristics of three pomegranate (Punica granatum L) cultivars: Wonderful, Acco and Herskovitz
}

\author{
Serhat Usanmaz ${ }^{1}$, İbrahim Kahramanoğlu ${ }^{1,2, ~ *}$, Nihat Yılmaz ${ }^{3}$ \\ ${ }^{1}$ European University of Lefke, Faculty of Agricultural Sciences and Technologies, Cyprus, Mersin 10 Turkey \\ ${ }^{2}$ Alnar Pomegranates Ltd., Ataturk Ave. 109/1 Guzelyurt, Cyprus, Mersin 10 Turkey \\ ${ }^{3}$ Erciyes Üniversitesi, Safiye C1krıkcioglu Vocational College, Kayseri, Turkey
}

\section{Email address:}

ibrahimcy84@yahoo.com (İ. Kahramanoğlu)

\section{To cite this article:}

Serhat Usanmaz, İbrahim Kahramanoğlu, Nihat Y1lmaz. Yield and Pomological Characteristics of Three Pomegranate (Punica granatum L) Cultivars: Wonderful, Acco and Herskovitz. American Journal of Agriculture and Forestry. Vol. 2, No. 3, 2014, pp. 61-65.

doi: 10.11648/j.ajaf.20140203.12

\begin{abstract}
Pomegranate fruit has been associated with a high level of nutrients and many health benefits. This study evaluated the yield and pomological characteristics of three pomegranate cultivars: Wonderful, Acco and Herskovitz grown in Cyprus conditions. Researches performed by collecting data from 17 pomegranate orchards between 2011 (4 years old) and 2012 (5 years old). Yield (kg/tree) was determined according to total harvest. Ten samples were randomly selected from each orchard and each cultivar to determine average fruit weight, number of arils per fruit, fruit width and height, aril per cent, juice per cent and total soluble solids. Results indicated that the Wonderful cultivar had the highest fruit weight and second highest yield (481.12 g/fruit and $14.17 \mathrm{~kg} /$ tree). The second highest fruit weight was obtained from Herskovitz which had the highest yield (431.04 g/fruit and $15.44 \mathrm{~kg} /$ tree). The lowest fruit weight and yield obtained from Acco (350.31 g/fruit and $11.43 \mathrm{~kg} /$ tree). Acco had highest juice content followed by Wonderful and Herskovitz $(40.22 \%>35.60 \%>29.42 \%)$. Wonderful had the highest juice content (5.05 1/tree). Juice content per tree for Acco and Herskovitz were determined 4.581 and 4.531 , respectively.
\end{abstract}

Keywords: Pomegranate, Yield, Juice Per Cent, Aril Per Cent, Fruit Weight, Fruit Diameter

\section{Introduction}

Pomegranate was one of the first five crops together with figs, dates, olives and grapes which are old known cultivated plants. Domestication of pomegranate started $3000-4000 \mathrm{BC}$ in the North of Iran and Turkey [1]. Pomegranate (Punica granatum L.) belongs to the Punicaceae family with two species namely: Punica granatum L. and P. protopunica Balf. P. protopunica is reported to be endemic to the Socotra Island and is the only congeneric relative of P. granatum $[2,3]$. Pomegranates are native to central Asia $[4,5]$ and are adaptable to a wide range of climate and soil conditions. Thus, it is grown in many different geographical regions including the Mediterranean basin, Asia and California.

Pomegranate fruit has been traditionally known to include high level of nutrients and many health benefits. Recent scientific findings confirm traditional usage of pomegranate for medical purposes [6] and reported that tissues of pomegranate fruit, flowers, bark and leaves contain bioactive phytochemicals that are antimicrobial, reduce blood pressure and act against serious diseases such as diabetes and cancer. It is also a good source of antioxidants, three times of wine or green tea, vitamins as it includes vitamin $\mathrm{A}, \mathrm{C}$ and $\mathrm{E}$ and a good source of potassium, calcium, magnesium, iron and zinc. Many studies conducted about pomegranates [7, 8, 9, $10,11]$ and revealed the benefits of pomegranate for human health. The findings of these studies increased the public awareness about pomegranate and thus consumption of pomegranate fruit increased. Total pomegranate import for the European Union countries was 171,993 tons in 2002 and it reached 269,093 tons in 2012. This means 56.5\% increase in 10 years [12].

In Cyprus, it is known that pomegranate was grown for fresh consumption and exportation during early 1900 [13]. However, from 1960 to 2007, number of pomegranate trees was decreased and only remained around other fruit 
orchards as wind barriers. Since there is a huge increase in the demand for the pomegranates, new plantations started to be constituted since 2007 with the "alternative crops" projects of USAID in Cyprus. The project funded by USAID and implemented by the Economic Development and Growth for Enterprises (EDGE) Project. Seventeen voluntary farmers attended to this project and established totally around 22 ha of pomegranate orchards.

Determination of the pomological characteristics of fruits is an important aspect for producers, packers, juice producers, marketers and consumers. It is also important for the engineers to design equipment and processes for harvesting, handling, sorting, sizing, packing, storing and processing. Several researches [14-20] reported a great variation in pomological characteristics among the pomegranate cultivars. Moreover, no information is available for the pomegranate cultivars grown in Cyprus. Therefore, this study aimed to assess and compare some pomological and yield characteristics of the three cultivars of pomegranates: Wonderful, Acco and Herskovitz.

\section{Materials and Methods}

\subsection{Materials}

This study performed by collecting data from 17 pomegranate orchards between 2011 (4 years old) and 2012 (5 years old). Each orchard covers 1.3 ha with $80 \%$ coverage of Wonderful cultivar, $10 \%$ with Acco and 10\% with Herskovitz. Wonderful cultivar (originated in Florida and first propagated in California) has sweet-tart taste, deep purple-red fruits with soft seeds and delicious vinous flavour. Herskovitz (Israel cultivar: 116) has sour taste fruits with red skin and hard seeds whereas Acco (Israel cultivar: 128) has very sweet, good quality fruits with pinky skin and notably softer seeds.

All fields are suitable for growing pomegranates with clay loam soil and moderate water salinity (Table 1.).

Table 1. Soil and water characteristics of the studied orchards.

\begin{tabular}{cccccc}
\hline $\begin{array}{c}\text { Orchard } \\
\text { Code }\end{array}$ & pH & Lime\% & Salinity \% & $\begin{array}{c}\text { Org. } \\
\text { Matter } \%\end{array}$ & $\begin{array}{c}\text { Water } \\
\text { salinity } \\
\text { (ppm) }\end{array}$ \\
\hline O-1 & 7.3 & 6 & 0.19 & 3 & 1420 \\
O-2 & 7.5 & 42 & 0.09 & 1.85 & 3230 \\
O-3 & 7.4 & 6 & 0.11 & 1.9 & 705 \\
O-4 & 7.5 & 17 & 0.09 & 0.7 & 1600 \\
O-5 & 7.5 & 20 & 0.05 & 1.3 & 1600 \\
O-6 & 7.5 & 15 & 0.12 & 2.3 & 950 \\
O-7 & 7.4 & 29 & 0.07 & 1.33 & 3700 \\
O-8 & 7.5 & 9 & 0.09 & 2.2 & 1250 \\
O-9 & 7.4 & 13 & 0.12 & 1.2 & 950 \\
O-10 & 7.6 & 2 & 0.13 & 1.9 & 1050 \\
O-11 & 7.4 & 3 & 0.09 & 1.7 & 1360 \\
O-12 & 7.5 & 12 & 0.11 & 1.7 & 1410 \\
O-13 & 7.4 & 10 & 0.08 & 1.3 & 1380 \\
O-14 & 7.9 & 10 & 0.12 & 1.7 & 1500 \\
O-15 & 7.4 & 10 & 0.13 & 1.7 & 1250 \\
O-16 & 7.5 & 1 & 0.09 & 1.7 & 800 \\
O-17 & 7.6 & 2 & 0.1 & 2.5 & 1800 \\
\hline
\end{tabular}

All orchards were established by $5 \times 3 \mathrm{~m}$ distance and pruned as globe shape with one trunk. Minimum temperature was $5.4 \mathrm{C}$ (in February) and Maximum temperature was $33.7 \mathrm{C}$ (in August). Average minimum and maximum temperatures were $11.6 \mathrm{C}$ and $24.7 \mathrm{C}$ respectively whereas total precipitation was $315 \mathrm{~mm}$ in 2012. Irrigation is performed by drip irrigation according to the basic needs and rainfall (Table 2.).

Table 2. Pure nitrogen (N), phosphorus $(P)$, potassium $(K)$ and water requirements of pomegranate trees.

\begin{tabular}{|c|c|c|c|c|c|c|c|c|}
\hline \multirow{3}{*}{ Months } & \multicolumn{6}{|c|}{ Pure nutrient (gr) / tree / month } & \multicolumn{2}{|c|}{ Water (I) / tree / day } \\
\hline & \multicolumn{3}{|c|}{4 years old } & \multicolumn{3}{|c|}{5 years old } & \multirow{2}{*}{$\begin{array}{l}4 \text { years } \\
\text { old }\end{array}$} & \multirow{2}{*}{$\begin{array}{l}5 \text { years } \\
\text { old }\end{array}$} \\
\hline & $\mathbf{N}$ & $\mathbf{P}$ & $\mathbf{K}$ & $\mathbf{N}$ & $\mathbf{P}$ & $\mathbf{K}$ & & \\
\hline January & 0,0 & 0,0 & 0,0 & 0,0 & 0,0 & 0,0 & 0 & 0 \\
\hline February & 0,0 & 0,0 & 0,0 & 0,0 & 0,0 & 0,0 & 0 & 0 \\
\hline March & 12,5 & 30,0 & 0,0 & 15,0 & 45,0 & 0,0 & 11 & 13 \\
\hline April & 62,5 & 36,0 & 0,0 & 75,0 & 54,0 & 0,0 & 19 & 21 \\
\hline May & 62,5 & 42,0 & 20,0 & 75,0 & 63,0 & 25,0 & 22 & 27 \\
\hline June & 50,0 & 12,0 & 40,0 & 60,0 & 18,0 & 50,0 & 28 & 40 \\
\hline July & 37,5 & 0,0 & 50,0 & 45,0 & 0,0 & 62,5 & 32 & 50 \\
\hline August & 25,0 & 0,0 & 50,0 & 30,0 & 0,0 & 62,5 & 32 & 45 \\
\hline September & 0,0 & 0,0 & 40,0 & 0,0 & 0,0 & 50,0 & 28 & 40 \\
\hline October & 0,0 & 0,0 & 0,0 & 0,0 & 0,0 & 0,0 & 24 & 30 \\
\hline November & 0,0 & 0,0 & 0,0 & 0,0 & 0,0 & 0,0 & 0 & 0 \\
\hline December & 0,0 & 0,0 & 0,0 & 0,0 & 0,0 & 0,0 & 0 & 0 \\
\hline Yearly / tree & 250 & 120 & 200 & 300 & 180 & 250 & 5880 & 7980 \\
\hline
\end{tabular}

Cultivation and management practices of the 17 orchards are same. Studied orchards generally face with Alternaria sp., Aphids (Aphis punica and Aphis pomi), Deudorix livia,
Zeuzera pyrina, Planocochus citri and Ceratitis capitata. Management program for these pests and diseases is given in Table 3. 
Table 3. Management program of the pomegranate pests and diseases.

\begin{tabular}{|c|c|c|}
\hline Months & Pests and diseases & Management \\
\hline $\begin{array}{l}\text { December - } \\
\text { February }\end{array}$ & Alternaria sp. & $\begin{array}{l}\text { Copper sulphate } \\
\text { application is used }\end{array}$ \\
\hline March - May & $\begin{array}{l}\text { Aphids (Aphis punica } \\
\text { and Aphis pomi) }\end{array}$ & $\begin{array}{l}\text { Acetamiprid or } \\
\text { Primicarb is used }\end{array}$ \\
\hline March - May & Deudorix livia & $\begin{array}{l}\text { Indoxacarb or Spinosad } \\
\text { is used }\end{array}$ \\
\hline May - August & Zeuzera pyrina & $\begin{array}{l}\text { Chlorpyrifos Ethyl is } \\
\text { used }\end{array}$ \\
\hline $\begin{array}{l}\text { June - } \\
\text { September }\end{array}$ & Planocochus citri & $\begin{array}{l}\text { Spirotetramat application } \\
\text { and fruit thinning is } \\
\text { performed }\end{array}$ \\
\hline $\begin{array}{l}\text { August - } \\
\text { November }\end{array}$ & Ceratitis capitata & $\begin{array}{l}\text { Attract-and-kill traps and } \\
\text { Cypermethrine are used }\end{array}$ \\
\hline
\end{tabular}

\subsection{Methods}

Seventeen orchards with three pomegranate cultivars: Wonderful, Acco and Herskovitz were used for this study. Orchards were checked monthly and data collected from February 2011 to November 2012. Pomological and yield data of the selected seventeen orchards were collected regularly and evaluated. The data includes; fruit weight, yield $(\mathrm{kg} /$ tree $)$, number of arils per fruit, fruit width and height, percentage of fruit bark, aril yield, fruit juice yield and total soluble solids (TSS). Harvested pomegranates were packed and stored at the packing house of Alnar Pomegranates Ltd. Total yield of each orchard divided to the number of trees to determine the yield $(\mathrm{kg} / \mathrm{tree})$. Thus, 10 fruits were selected randomly from each orchard, for each cultivar and physical properties were determined. Fruit weight was measured by using digital scale (sensitive to $\pm 0.01 \mathrm{~g}$ ). Number of arils per fruit was determined by extracting the arils carefully by hand. Fruit width and height were measured by a digital caliper with $\pm 0.01 \mathrm{~mm}$ accuracy. Percentage of aril was determined by using digital scale $( \pm 0.01 \mathrm{~g})$. Percentage of juice was calculated with simple formula as percentage after squeezing the arils and TSS in the juice were determined with a hand refractometer ( ${ }^{\circ}$ Brix). Data from the two year experiments were subjected to ANOVA to determine any statistical differences among species. Mean separations were done by using the Duncan's multiple range test at $\mathrm{P}<0.01$.

\section{Results}

Fruit characteristics and yield of three pomegranate cultivars are given in Table 4 . The yield were recorded among cultivars $(\mathrm{P}<0.01)$ with no significant differences. According to the results, it is clear that the highest fruit weight is obtained in the Wonderful (461.72 g) followed by Herskovitz (412.15 g) and Acco cultivars (336.23 g) in 2011 of 4 years old trees. The average fruit mass of pomegranate cultivars ranged from $350.31 \mathrm{~g}$ to $481.12 \mathrm{~g}$ for 5 years old trees. Results for the fruit width and height are in accordance with the results for fruit weight. When comparing the cultivars, the highest width and height were determined in the order of Wonderful > Herskovitz $>$ Acco in both years. In 2012, when the trees are 5 years old, average fruit width and height were $107.12 \mathrm{~mm}$ and $93.90 \mathrm{~mm}$ for Wonderful, $97.03 \mathrm{~mm}$ and $83.81 \mathrm{~mm}$ for Herskovitz and $81.60 \mathrm{~mm}$ and $68.38 \mathrm{~mm}$ for Acco. No statistical significance was reported when comparing the yields of three cultivars. However, on the other hand, it is clear from the two years results that Herskovitz is having higher yield than the Wonderful and Acco.

Pomological characteristics of three pomegranate cultivars are presented in Table 5. Statistically significant differences were determined among cultivars $(\mathrm{P}<0.01)$. The average number of arils per fruit for cultivars varied from 539.41 to 759.23 in 2011 and from 560.09 to 790.95 in 2012. These results are in accordance with the fruit weight, width, height and yield results where all characteristics are increased in 2012. Significant differences were obtained in fruit aril per cent and fruit juice per cent for the three cultivars. For the other characteristics, like fruit weight and number of arils, are recorded high for the Wonderful cultivar whereas the percentage of aril and juice are recorded high for Acco cultivar. The aril and juice per cent of three cultivars were slightly higher in 2012 than 2011 without significant differences. The aril per cent of Acco, Wonderful and Herskovitz is $68.32 \%$, $60.55 \%$ and $58.36 \%$, respectively, in 2012 . Results for the juice per cent of three cultivars are in accordance with the results for aril per cents. The highest juice content is recorded for Acco (40.22\%) and followed by Wonderful (35.57\%) and Herskovitz (29.42\%). Total soluble solid contents of the studied cultivars ranges from 16.00 to 21.45 .

Table 4. Fruit characteristics and yield of pomegranate cultivars: Wonderful, Acco and Herskovitz

\begin{tabular}{|c|c|c|c|c|c|}
\hline \multicolumn{2}{|c|}{ Ages and Cultivars } & \multirow{2}{*}{$\begin{array}{c}\text { Average Fruit weight (g) } \\
461.72 \mathrm{a}\end{array}$} & \multirow{2}{*}{$\begin{array}{c}\begin{array}{c}\text { Average Fruit width } \\
\text { (mm) }\end{array} \\
104.91 \mathrm{a}\end{array}$} & \multirow{2}{*}{$\begin{array}{c}\begin{array}{c}\text { Average Fruit height } \\
\text { (mm) }\end{array} \\
90.92 \mathrm{a}\end{array}$} & \multirow{2}{*}{$\begin{array}{c}\text { Average Yield (kg/tree) } \\
8.21 \pm 7.05 \mathrm{a}\end{array}$} \\
\hline & Wonderful & & & & \\
\hline 4 years old & Acco & $336.23 \mathrm{c}$ & $80.04 \mathrm{c}$ & $66.82 \mathrm{c}$ & $8.35 \pm 6.73 \mathrm{a}$ \\
\hline \multirow{4}{*}{5 years old } & Herskovitz & $412.15 \mathrm{~b}$ & $95.59 \mathrm{~b}$ & $82.37 \mathrm{~b}$ & $13.71 \pm 8.63 \mathrm{a}$ \\
\hline & Wonderful & $481.12 \mathrm{a}$ & $107.12 \mathrm{a}$ & $93.90 \mathrm{a}$ & $14.17 \pm 8.13 \mathrm{a}$ \\
\hline & Acco & $350.31 \mathrm{c}$ & $81.60 \mathrm{c}$ & $68.38 \mathrm{c}$ & $11.43 \pm 7.64 \mathrm{a}$ \\
\hline & Herskovitz & $431.04 \mathrm{~b}$ & $97.03 \mathrm{~b}$ & $83.81 \mathrm{~b}$ & $15.44 \pm 10.13 \mathrm{a}$ \\
\hline \multicolumn{2}{|c|}{ Significance level } & 0.01 & 0.01 & 0.01 & NS \\
\hline
\end{tabular}


Table 5. Some pomological characteristics of pomegranate cultivars: Wonderful, Acco and Herskovitz

\begin{tabular}{|c|c|c|c|c|c|}
\hline \multicolumn{2}{|c|}{ Ages and Cultivars } & \multirow{2}{*}{$\begin{array}{l}\text { Average number of arils per fruit } \\
759.23 \mathrm{a}\end{array}$} & \multirow{2}{*}{$\begin{array}{l}\text { Percentage of aril } \\
60.47 \mathrm{~b}\end{array}$} & \multirow{2}{*}{$\begin{array}{l}\text { Percentage of juice } \\
35.57 \mathrm{~b}\end{array}$} & \multirow{2}{*}{$\frac{\text { TSS (oBrix) }}{21.42 \mathrm{a}}$} \\
\hline \multirow{3}{*}{4 years old } & Wonderful & & & & \\
\hline & Acco & $539.41 \mathrm{c}$ & $68.09 \mathrm{a}$ & $40.08 \mathrm{a}$ & $17.22 \mathrm{~b}$ \\
\hline & Herskovitz & $666.17 \mathrm{~b}$ & $58.30 \mathrm{c}$ & $29.39 \mathrm{c}$ & $15.81 \mathrm{c}$ \\
\hline \multirow{3}{*}{5 years old } & Wonderful & $790.95 \mathrm{a}$ & $60.55 \mathrm{~b}$ & $35.60 \mathrm{~b}$ & $21.45 \mathrm{a}$ \\
\hline & Acco & $560.09 \mathrm{c}$ & $68.32 \mathrm{a}$ & $40.22 \mathrm{a}$ & $17.29 \mathrm{~b}$ \\
\hline & Herskovitz & $694.62 \mathrm{~b}$ & $58.36 \mathrm{c}$ & $29.42 \mathrm{c}$ & $16.00 \mathrm{c}$ \\
\hline \multicolumn{2}{|c|}{ Significance level } & 0.01 & 0.01 & 0.01 & 0.01 \\
\hline
\end{tabular}

\section{Discussions}

The fruit weight of five year old trees showed considerable variation with the fruit weight of $481.12 \mathrm{~g}$ for Wonderful, $431.04 \mathrm{~g}$ for Herskovitz and $350.31 \mathrm{~g}$ for Acco during 2012 due to early ripening of Acco and Herskovitz cultivars. Pantelidis, et al. [21] reported that the mean fruit weight of Wonderful and Acco cultivars are $474.2 \mathrm{~g}$ and $273.6 \mathrm{~g}$, respectively, in Greece but the fruit weight of Acco in present study is significantly higher. On the other hand, Bartual, et al., [22] reported that the average fruit of Wonderful cultivar is $324.86 \mathrm{~g}$ in Spain, which is significantly lower than the results of present study. A wide variation among the fruit mass of different pomegranate cultivars ranging from $103 \mathrm{~g}$ to $505 \mathrm{~g}$ were reported [14-16, 18-20].

Fruit width and height results are in accordance with the results for fruit weight. Moreover, recent studies reported that fruit width is ranging from 60.6 to $106.99 \mathrm{~mm}$ and fruit height of 52.9 to $95.52 \mathrm{~mm}$ [16-18]. Similarly with fruit mass, fruit width and height of pomegranate cultivars under study are in accordance with the findings of previous works but the fruit weight of Wonderful (2012) is higher than the other pomegranate cultivars studied in other researches: Eksinar, Hicaznar, Ciparski, Konjski and Pastun. The Acco and Herskovitz are early cultivars with smaller dimensions and less ripening period than Wonderful. The yield of three cultivars of 4 and 5 years old is found to be superior over the fruit yield of Malas e Torsh e Saveh (Iran cultivars; 8.10 $\mathrm{kg} /$ tree) [19]. It is observed that some orchards have recorded significant difference in fruit yield as reported here: $31.6 \mathrm{~kg} /$ tree for Wonderful, $31.4 \mathrm{~kg} /$ tree for Acco and $39.8 \mathrm{~kg} /$ tree for Herskovitz.

The number of arils per fruit indicated that there is a significant difference among the cultivars. The number of arils per fruit for Wonderful is 790.9, 694.6 for Herskovitz and 560.9 for Acco. Results indicated that both three cultivars under study have superior aril content to that of the Eksinar which is having mean of 502 and maximum of 618 arils per fruit [16]. The aril per cent of Acco, Wonderful and Herskovitz are $68.3 \%, 60.6 \%$ and $58.3 \%$, respectively. The significant edible percent for Wonderful and Acco were reported in Greece [21] for the same cultivars as 53.0\% and $53.6 \%$, respectively. Some previous studies reported a wide variation among the aril per cent for different pomegranate cultivars ranging from 46.30 to $68.31[15,16,20]$.

The Acco cultivar have 40.22 per cent of juice content whereas 35.57 per cent for Wonderful and 29.42 per cent for Herskovitz. Similar kind of observations was reported with 34 to 35 per cent juice content in Wonderful cultivar [21, 22]. The juice content of Acco cultivar (two years of experimental results) is higher to that of the same cultivar grown in Greece (37.9\%) [21]. Akbarpour, et al., [15] reported that the juice content of 12 cultivars in Iran varies from $20.18 \%$ to $59.83 \%$ but of Spanish varieties with juice content of $50.26 \%$ to $64.17 \%$ [23]. Total soluble solid contents of the cultivars vary from 16.00 to 21.45 . These findings are in accordance with the results of other works $[15,19,20]$. Among the studied cultivars, Wonderful has the TSS content of 21.45 followed by Acco (17.29) and Herskovitz (16.00). This observation is in agreement with the reports of research workers in Greece and Spain [21, 22]

\section{Conclusions}

Results of present study showed considerable variation in the pomological characteristics of widely grown pomegranate cultivars under Cyprus conditions. Wonderful cultivar is the best for fruit size production. But no statistical difference was determined among cultivars in spite of good performance of Herskovitz (15.4 kg/tree, Table 6).

Table 6. Summary results for the two years average of yield and fruit Juice for Wonderful, Acco and Herskovitz.

\begin{tabular}{cccc}
\hline Cultivars & $\begin{array}{c}\text { Average yield } \\
\text { (kg/tree) }\end{array}$ & $\begin{array}{c}\text { Fruit Juice (\% of } \\
\text { a fruit) }\end{array}$ & $\begin{array}{c}\text { Fruit Juice (I } \\
\text { / tree) }\end{array}$ \\
\hline Wonderful & 14.2 & 35.59 & 5.05 \\
Acco & 11.4 & 40.15 & 4.58 \\
Herskovitz & 15.4 & 29.40 & 4.52 \\
\hline
\end{tabular}

Because of the sour taste, the Herskovitz is not having good marketing potential and thus the Wonderful cultivar, with its sweet-tart taste and high yield, seems to be the best cultivar for fresh consumption. The Acco cultivar's performance is poor with low pomological characteristics such as fruit weight, yield, width, height and number of arils but have good aril and juice per cents: $68.32 \%$ and $40.15 \%$. Considering the yield ( $\mathrm{kg} /$ tree) and juice content 
(\%) together, again the Wonderful cultivar is good with juice content of 5.051 per tree.

\section{Acknowledgment}

Special thanks to USAID and EDGE Project for the alternative crops project, which gave chance to the farmers to produce pomegranates and made this study possible. Authors gratefully acknowledge to Prof. Dr. Kazım Abak for his valuable advice and to Mr. Erdinc Bilgin, chairman of Cyprus Pomegranate Producers Union for his kind help.

\section{References}

[1] C. Lye, "Pomegranate: preliminary assessment of the potential for an Australian industry" Rural Industries Research and Development Corporation of Australian Government. RIRDC Publication No 08/153, 2008, 17p.

[2] D., Chatterjee and G. S. Randhawa, "Standardized names of cultivated plants in India. 1. Fruits". Indian J. Hort. Vol. 9, 1952, pp.24-36.

[3] C. Yılmaz, "Nar" Hasad Yayıncılık, 2007, 190p.

[4] J. Morton, "Pomegranate". In: Fruits of warm climates. Miami, F, L. 1987, pp. 352-355.

[5] D. Holland, K. Hatip and I. Bar-Ya'akov, "Pomegranate: Botany, Horticulture and Breeding", Horticultural Reviews, Volume, 35, Edited by Jules Janick, John Wiley \& Sons Inc, 2009, pp.127-191.

[6] J. M. T. Jurenka, “Therapeutic Applications of Pomegranate (Punica granatum L.): A Review", Alternative Medicine Review Vol. 13, No. 2, 2008, pp.128-144.

[7] M. I. Gil, F. A. Tomas-Barberan, B. Hess-Pierce, D.M. Holcroft and A. A. Kader, "Antioxidant activity of pomegranate juice and its relationship with phenolic composition and processing", J. Agric. Food Chem. Vol. 48, 2000, pp.4581-4589.

[8] M. Aviram and L. Dornfeld, "Pomegranate juice consumption inhibits serum angiotensin converting enzyme activity and reduces systolic blood pressure", Atherosclerosis Vol. 158, 2001, pp.195-198.

[9] E. P. Lansky, W. Jiang, H. Mo, L. Bravo, P. Froom, W. Yu, N.M. Harris, I. Neeman and M.J. Campbell, "Possible synergistic prostate cancer suppression by anatomically discrete pomegranate fractions", Invest New Drug, Vol. 23, 2005, pp.11-20.

[10] M. Haidari, M. Ali, S.W. Casscells and M. Madjid, "Pomegranate (Punica granatum) purified polyphenol extract inhibits influenza virus and has a synergistic effect with oseltamivir", Phytomedicine, Vol. 16, No. 12, 2009, pp.1127-36.

[11] G. Turk, M. Sonmez, M. Aydin, A. Yuce, S. Gur, M. Yuksel, E.H. Aksu and H. Aksoy, "Effects of pomegranate juice consumption on sperm quality, spermatogenic cell density, antioxidant activity and testosterone level in male rats", Clinical Nutrition Vol. 27, 2008, pp.289-296.

[12] EC Market Access Database, European Commission, Market Access Database. http://madb.europa.eu/madb/ statistical_form.htm, access date: 01 July 2013.

[13] W. Bevan, "Notes On Agriculture in Cyprus and its Products". London, Hazell, Watson \& Vinery, ld., printers, 1919.

[14] Y. Ozkan, "Determination of pomological characteristics of Niksar district pomegranates (Punica granatum L.) of the Tokat Province". Acta Hort. Vol. 598, 2003, pp.199-203.

[15] V. Akbarpour, K. Hemmati and M. Sharifani, "Physical and chemical properties of pomegranate (Punica granatum L.) fruit in maturation stage". American-Eurasian J. Agric. \& Environ. Sci. Vol. 6, No. 4, 2009, pp.411-416.

[16] A. Celik and S. Ercisli, "Some physical proterties of pomegranate cv. Eksinar", Int. Agrophysics Vol. 23, 2009, pp.295-298.

[17] S. Gozlekci, S. Ercisli, F. Okturen, and S. Sonmez, "Physico-chemical characteristics at three development stages in pomegranate cv. Hicaznar". Not. Bot. Hort. Agrobot Cluj Vol. 39, No. 1, 2011, pp.241-245.

[18] J. Gazde, S. Voca, Z. Cmelik, I. Mustac, S. Ercisli and Radunic, "Physico-chemical characteristics of main pomegranate (Punica granatum L.) cultivars grown in Dalmatia region of Croatia”, J. App. Bot. Food Quality, Vol. 85, 2012, pp.202-206.

[19] M. Hasani, Z. Zamani, G. Savaghebi and R. Fatahi, "Effects of zinc and manganese as foliar spray on pomegranate yield, fruit quality and leaf minerals", J. Soil Sci. Plant Nutr. Vol. 12, No. 3, 2012, pp.471-480.

[20] M. M. Mir, I. Umar, S.A. Mir, M.U. Rehman, G.H. Rather and S.A. Banday, "Quality Evaluation of Pomegranate Crop - A review", International Journal of Agriculture \& Biology Vol. 14, 2012, pp.658-667.

[21] G. Pantelidis, P. Drogoudi and A. Manganaris, "Physico-chemical and antioxidant properties of pomegranate genotypes in Greece", Options Mediterraneenes Vol. 103, 2012, pp.335-337.

[22] J. Bartual, H. Valdes, J. Andreu, A. Lozoya, J. Garcia and M.L. Badenes, "Pomegranate improvement through clonal selection and hybridization in Elche", Options Mediterraneenes Vol. 103, 2012, pp.71-74.

[23] J. J. Martinez, P. Melgarejo, F. Hernandez, D.M. Salazar and R. Martinez, "Seed characterisation of five new pomegranate (Puica granatum L.) varieties", Scienta Horticulturae, Vol. 110, No. 3, 2006, pp.241-246. 